\title{
Minor Political Geographies
}

For special section on the minor, Joe Gerlach and Thomas Jellis (eds.) for Environment and Planning D: Society and Space

Accepted version, Environment and Planning D: Society and Space, 35, 4, 589-592

\section{Andrew Barry}

In their short book on Kafka, subtitled 'towards a minor literature', Deleuze and Guattari define a minor literature in a straightforward way. First they inform us that 'a minor literature doesn't come from a minor language; it is rather that which a minority constructs within a major language' (1986: 16). Kafka is the ideal type of an author writing in a minor literature according to Deleuze and Guattari. He was a Jew writing in German living in Prague. 'The impossibility of writing other than in German is for the Prague Jews the feeling of the irreducible distance from their primitive Czech territoriality'. Kafka has to write in a language that is foreign to the city that he inhabits. In short, Prague German is a deterritorialized language' as Deleuze and Guattari put it. It is German, but written by a non-German outside of Germany. It reads like German, but it is also different from or a variation of German.

'A second characteristic of a minor literatures', Deleuze and Guattari inform us, is that 'everything in them is political' (ibid: 17). The statement is significant, but is also misleading. For when Deleuze and Guattari speak of the political they don't mean political in the conventional sense. The political doesn't necessarily refer to the realm of the state or to the activities of political parties. But neither do they take the political to be an index of disagreement, along the lines suggested by Chantal Mouffe or Jacques Rancière, for example. Deleuze and Guattari's account of politics seems far too overgeneralised; it lacks any account of the specificity of politics at all. Nonetheless, they do define the concept further. In their account, a minor literature is political because of the way in which the particular and the individual are automatically connected to what they term 'the social mileu'; 'the individual concern thus becomes all the more necessary, indispensible, magnified, because a whole other story is vibrating within it' (ibid: 17, my emphasis). The contributor to a minor literature is likely to work in what they term 
'cramped spaces', within which the force and constraint of the social milieu is directly felt. Furthermore, the minor literature is micropolitical because it introduces variations, which may be quite small, but which make a difference. It is a marker of a movement of differentiation, without the nature of this difference being ordained in advance, or understood merely in opposition to what has existed before.

2.

Accounts of the discipline of Geography have often started from the assumption that it is or should be what Deleuze and Guattari would call major language. After all, geographers have understood their discipline to be an integrated or holistic science that, in principle, encompasses other disciplines; or alternatively they have lamented the fact that the project of integration or interdisciplinary synthesis has failed, even within the circumscribed space of the region. In this context, the continuing cohabitation of human and physical geographers is largely the product of the path-dependent history of the discipline; it lacks any conceptual rationale. My contention is that one starting point for rethinking the scope of geography would be to acknowledge that geographical thought and practice has elements of what we might call a minor language all along. To formulate my proposition crudely: as Kafka wrote a form of German which was necessarily a variation of German, geographers may have write in the major languages of the natural and social sciences and humanities, but often do so, and arguably should do so, in a minor register. My aim here is to recognize the value of the minor in geography. Minor composition, as Nicholas Thoburn observes, does not lead towards 'a synthesis, but an amplification of disjunctions' (Thoburn 2003: 27).

Physics and Sociology are good examples of disciplines in which major forms of thought are, in principle, highly valued. The idea that it is possible to establish to arrive at general principles or universal laws is central to the identity of physics, after all. Indeed, it is this aspect of physics - its tendency towards reductionism and synthesis - that is the principle target of the work of the Belgian philosopher Isabelle Stengers. Her seven volume Cosmopolitiques is centrally concerned with the relation between the major language of physics and we can term, following Deleuze and Guattari, the minor language of physical chemistry. The curious thing about the Cosmopolitiques series is that most of it is not about what is conventionally understood to be politics at all. It is actually about the history of 
thermodynamics, but in the context of Stengers' argument her focus on thermodynamics, rather than politics, makes sense. In effect, Stengers' work challenges the hierarchical relation that is often assumed to exist relation between physics (as the repository of general principles) and chemistry (as an applied practice) (Stengers 2010, Barry 2015a\&b). She does this by focusing our attention on the significance of thermodynamics, the key set of theoretical principles about the relation between energy and entropy that underpins the interdisciplinary field of physical chemistry. In the conventional story, the principles of thermodynamics are, in the end, reducible to the more fundamental principles of physics. By contrast, Stengers reads thermodynamics as a way of thinking about the irreducibility of physical systems to these principles. In the specific context of the physical sciences, physical chemistry becomes something like a minor language, which sounds like physics, but actually introduces an irreducible variation to physics, challenging the order of the disciplines. Rather than a hierarchical system of disciplines, thermodynamics directs us to the possibility of what Stengers terms an ecology of practices. For Stengers, practitioners need to learn to shrug their shoulders as she puts it, 'at the claims of the great generalizing theoreticians'. The lesson is an important one for those concerned with the study of politics (Barry 2013, chapter 7).

Sociology, too, has frequently been formulated and understood in a major register. Social theorists have sometimes sought to determine the evolution or state of society in general, or to classify society according to its major divisions. Indeed, Guattari himself condemned what he terms 'sociological analytic formalist thought' because of its tendency to classify and 'determine absolute differences' between societies and political systems (Guattari 2009: 156). For Deleuze and Guattari, however, it was Marxism and psychoanalysis rather physics and sociology that generated the most influential 'major' or molar forms of political thought. On the one hand, Deleuze and Guattari were opposed to the particular institutionalization of psychoanalysis, in its Lacanian formulation, and its fixation on the Oedipal relation. Guattari was not antagonistic to psychoanalysis in principle, but sought to develop a form of analysis that is not 'necessarily centred human subjectivity' and 'the old territories of Ego, family, profession, religion, ethnicity etc.' but with diverse material fluxes and social systems (ibid. 197). On the other hand, although Deleuze and Guattari were critical of a Marxist system that, as Guattari put it, 'constitutes itself as the collective system of representation of the masses' desires' (ibid.: 157) they nonetheless affirmed that 'they remained Marxists, in our different ways' 
(Deleuze 1990: 171). They were not hostile to Marxism per se, but rather to its association with the exclusion or suppression of minor forms of thought, practice, and expression. The challenge that they pose is how to offer a minor reading of both the Marxist and psychoanalytic traditions and the politics of capitalism (Thoburn 2003).

3.

Perhaps the concept of the minor has particular relevant to the political geography of materials and sciences, as Stengers' work suggests. Political geography is likely to have to attend to a range of things, from biological organisms to seismic faults, which cannot be readily understood in the terms of a major language of social and political thought (Hird 2010, Barry 2013). In this context, the political geographer may need to draw on the arguments and knowledge claims of the natural sciences, but should not aspire to integrate the natural and social sciences, thereby eliding the differences between distinct social, biological and geophysical 'force-fields' (Born 2015). The political geographer may have to write about biological organisms and geophysical materials using the language of the natural sciences, but from a position on the margin of the natural sciences. Moreover, as Deleuze and Guattari's definition of the minor suggests, geographers should be particularly attentive not just to the major literatures of scientific research, but also to the significance of minor scientific literatures, including those generated from outside of dominant Euro-American institutions, by scientists who routinely experience working in 'cramped spaces'.

Prof Andrew Barry

Department of Geography

University College London

26 Bedford Way

London WC1H 0AP

a.barry@ucl.ac.uk

\section{References}

Barry A, (2013) Material Politics: Disputes along the Pipeline, Chichester: Wiley-Blackwell. Barry A, (2015) "Geography and other disciplines: genealogy, anamnesis and the canon", Journal of Historical Geography 49 85-93.

Barry A, (2015) "Thermodynamics, matter, politics", Distinkition: Scandinavian Journal of Social Theory, 16(1) 110-125.

Born G, (2015) "Making Time: temporality, history, and the cultural object", New Literary History, 46(3) 361-386. 
Deleuze G, (1990) Negotiations, New York: Columbia University Press.

Deleuze G and F Guattari (1986) Kafka: towards a minor literature, Minneapolis: Minnesota University Press.

Guattari F, (2009) Chaosophy: Texts and Interviews 1972-77, New York: Semiotext(e).

Hird, M, (2010) 'Indifferent globality: 'Gaia' symbiosis and other worldliness", Theory,

Culture and Society, 27 (2-3) 54-72.

Stengers I, (2010) Cosmopolitics I, Minneapolis: Minnesota University Press.

Thoburn N,(2003) Deleuze, Marx and Politics, London: Routledge. 